RESEARCH ARTICLE

\title{
Nuclear Matrix Protein 22 and Cytological Findings in Urine of Residents of Urogenital Schistosomiasis in an Endemic Community
}

\author{
Ukeme Gideon Etuk ${ }^{1}$, Paul Columba Inyang-Etoh ${ }^{1}$, Mfonisa Iniobong Udonkang ${ }^{1}$, Emmanuel Monday \\ Japhet $^{2}$, Uloma Opara-Osuoha ${ }^{3}$ \\ ${ }^{1}$ Department of Medical Laboratory Science, Faculty of Allied Medical Sciences, College of Medical Sciences, \\ University of Calabar, Calabar, Nigeria \\ ${ }^{2}$ Department of Surgery, University of Calabar Teaching Hospital, Calabar, Nigeria \\ ${ }^{3}$ Department of Biology, College of Science and Technology, Temple University, Philadelphia, USA
}

\begin{abstract}
Objective: Urogenital schistosomiasis has continued to cause severe morbidity among residents of Adim community The aim of the study was to screen both adults and children residents of this community for urine tumour markers and to stain cytologically for epithelial changes which indicate the risk of them being predispose to bladder cancer.

Methods: Terminal urine samples were collected by simple random sampling method from 350 subjects (300 children and 50 adults) in Adim Community for microscopy using standard parasitological methods, urinalysis, ELISAbased Nuclear Matrix Protein 22 (NMP22), and Papanicolaou- and Alcian blue-stained cytological analysis.

Results: S. haematobium infection was observed in 18 (5.1\%), proteinuria 21 (6.0\%) and hematuria 30 (8.6\%). Age group 25-31 years had the highest level of NMP22 values (1692.3 \pm 46.4$)$ among the adults and children. The difference was statistically significant $(P=0.001)$. In general male subjects had higher NMP22 values $(1214.6+487.1)$ than females $(1198.9+472.9)(P=0.389)$. The cytological findings showed abnormal epithelial cells in Papanicolaou stain $2(0.57 \%)$ and hyaluronic acid $1(0.29 \%)$. Cytological findings with Papanicolaou stain revealed metaplasia 1 $(0.3 \%)$, mild dysplasia $1(0.3 \%)$, inflammation $6(1.7 \%)$, and hyaluronic acid positive cells $1(0.29 \%)$.

Conclusion: The study showed $S$. haematobium prevalence of $5.1 \%$ but NMP 22 values were not positive for bladder cancer. The cytological findings revealed metaplasia, mild dysplasia and hyaluronic acid positive epithelial changes which are indicators for bladder cancer. J Microbiol Infect Dis 2018; 8(3):89-96
\end{abstract}

Keywords: Bladder cancer, Cytology, Nuclear Matrix Protein 22, Urogenital Schistosomiasis

\section{INTRODUCTION}

Schistosomiasis is the second most important parasitic disease after malaria [1]. Schistosoma haemotobium infects about 112 million individuals per year and cause about 150,000 deaths due to renal failure annually. Thus, it is the deadliest among all the species of schistosome [2]. According to World Health Organization/International Agency for Research on cancer (WHO/IRC), $S$. haematobium is classified as a class 1 carcinogen [2]. Bladder cancer is one of the pathology of urogenital schistososmiasis [2] and can be diagnosed with urine cytology, the gold standard method [3]. This method is very sensitive and specific in detecting high grade bladder cancer but has low sensitivity for low grade and early stage tumour [3]. Bladder cancer can also be diagnosed with Nuclear Matrix Protein 22 (NMP22), the first tumour marker approved by the US food and Drug Administration for its screening. Hyaluronic acid estimation in urine is another diagnostic marker for bladder cancer because its levels are increased in the urine of bladder cancer patients [4]. Urogenital schistosomiasis has been reported in Adim Community by various authors [5-11]. Thus, the aim of this study was to investigate nuclear matrix protein 22 (NMP22) levels and cytological findings in urine of residents of Adim Community, Nigeria and also

Correspondence: Dr. Paul Columba Inyang-Etoh, Medical Laboratory Science Department, Faculty of Allied Medical Sciences, College of Medical Sciences, University of Calabar, Calabar, Cross River State, Nigeria 
to evaluate their risk of being predispose to bladder cancer.

\section{METHODS}

\section{Study area}

This research was carried out in Adim Community which is a village in Biase Local Government Area, located about 110 kilometers to the North of Calabar, Cross River State. The inhabitants depend mostly on streams for their source of water. Farming is the major occupation of the inhabitants.

\section{Ethical clearance}

This was sought and obtained from the Cross River State Ministry of Health. The Community Head and the Head of school involved in the study were duly consulted. Informed consent from parents/guardians of subjects was sought and obtained.

\section{Study population}

The target population was primary school children and adults in the community and was selected through simple random sampling method.

\section{Administration of questionnaires}

Questionnaires comprising the demographic information, nature of occupation, water source for domestic chores and recreational activities, toilet as well as symptoms experienced recently were administered to the adult subjects. Similar information was obtained from the school pupil through interview. Serial numbers were assigned on the questionnaires. Sample bottles used in the investigation were labelled with these numbers accordingly.

\section{Sample collection}

Well labelled clean universal containers with the identification numbers of the subjects were given to the recruited pupils and adults for collection of urine sample. Collection of urine was done between 11.00 am and 2.00 pm when maximum egg excretion occurs [12].

\section{Examination of the samples for hematuria and proteinuria}

The urine samples were screened for hematuria and proteinuria using urinalysis test trips (MediTest combi 9 manufactured by Macherey-Nagel,
Düren, Germany). The result was read and recorded as described by Inyang-Etoh et al. [13].

\section{Examination of urine for ova of Schistosoma haematoblium}

Ten milliliters of the urine samples were transferred into universal containers containing 5 $\mathrm{ml}$ of $1 \%$ aqueous solution of carbol fuschin for staining and preservation of the ova [5]. The mechanical filtration technique by [7] was used.

\section{Cytological examination of urine}

Five milliliters of the urine sample was immediately put into $5 \mathrm{ml}$ of $95 \%$ ethanol to fix the cell constituent. This was emptied into a centrifuge tube and centrifuged at $3000 \mathrm{rpm}$ for five minutes. The deposit was used to make a smear on grease free albumenized slides prepared with egg albumen-glycerol adhesive. The albumen glycerol adhesive was prepared by mixing equal volume of egg albumen with glycerol and thymol crystal added to avoid the formation of moulds. Two slides were prepared from each sample. One was stained with Alcian blue stain at PH 2.5 to detect hyaluronic acid while the second slide was stained with Papanicolaou staining technique to assess atypical squamous epithelial cells as described by Bancroft and Gamble (Theory and practice of histological techniques. $6^{\text {th }}$ ed. Churchill Livingstone, London).

\section{Staining Result for Hyaluronic acid:}

Hyaluronic acid $\rightarrow$ blue (bluish green),

Nuclei $\rightarrow$ red, Control $\rightarrow$ small intestine $\rightarrow$ blue

Staining Result for Papanicolaou staining technique:

Nucleic $\rightarrow$ blue, Normal epithelial cells $\rightarrow$ pink,

Atypical epithelial cells $\rightarrow$ orange

Determination of nuclear matrix protein 22 (NMP 22)

Nuclear matrix protein 22 was assessed in the urine by using Human Nuclear Matrix Protein 22 ELISA Kit produced by Eastbiopharm, Hangzous, China. This was done according to the manufacturer's instruction on the test kit manual.

\section{Data analysis}


Statistical analysis was performed using a commercial statistical package: SPSS Version 20 for Windows. The mean NMP22 was expressed as Mean \pm standard deviation. The chi-squared $\left(\mathrm{X}^{2}\right)$ test and Fishers exact test were used in testing the associations between variables. $P$ value at $95 \%$ confidence interval was used to calculate the level of significance.

\section{RESULTS}

The distribution of morbidity indicators of $S$. haematobium infection by age of subjects is shown in Table 1. Children in the age group 1117 years had the highest infection rate $5(6.0 \%)$, proteinuria 9 (10.8\%) and hematuria 11 (13.3\%) but these were not statistically significant $\left(X^{2}=6.000, \quad P=0.199\right)$. The distribution of morbidity indicators of $S$. haematobium infection according to gender of subjects is shown on Table 2. Among the children, males had a higher infection rate 11 (9.7\%), proteinuria 15 (13.2\%) and hematuria $16(1 \%)$ than the females who had 7 (3.8\%), 6 (3.2\%) and 12 (6.5\%) respectively. The difference was not significant $\left(X^{2}=2.000, P=0.157\right)$. Adults had no infection and proteinuria, except hematuria which was observed among the females 2 (6.6\%).

The distribution of Mean NMP 22 values of infected versus uninfected subjects by age is shown in Table 3. There was no statistically significance of mean NMP 22 values between infected and uninfected subjects by age group $(F=0.147, P=0.864)$. Table 4 shows the mean
NMP22 of infected versus uninfected subjects by gender. The infected subjects had 1499.0 \pm 560.3 while the uninfected had $1188.8 \pm 468.3$. The difference was not significant $(F=0.402$, $P=0.676)$. The distribution of cytological findings of $S$. haematobium infection among subjects by age is shown on Table 5. The abnormal epithelial cells were found in age range of 39-45 years 1 (9.0\%) and 53-59 years 1 (25\%) while hyaluronic acid positive epithelial cells were found in 4-10 years old 1 (0.5\%). The distribution of cytological findings of $S$. haematobium infections according to gender of subjects is shown on Table 6 . The prevalence of abnormal epithelial cells in Papanicolaou stain was $2(0.6 \%)$ and detection of hyaluronic acid in Alcian blue stain was 1 (0.3\%). Abnormal epithelial cells $2(0.6 \%)$ were found in only females adults and one female child positive for hyaluronic acid $1(0.3 \%)$. The Fisher's exact test was not statistically significant $(P=0.333)$.

The photomicrographs are shown in Figures 1 and 2. Figure 1 Plate A shows two normal bladder epithelial cells $E$ faintly stained with hyaluronic acid while plate B shows a deep blue stained bladder epithelial cell $E$ positive for hyaluronic acid. Figure 2 Plate A shows normal epithelial cell $E$ with normochromic nucleus and Plate B shows metaplastic cells showing features of progression to cancer characterized by hyperchromatic nuclei $\mathrm{N}$, multi-nucleation with loss of cell membrane $M$ and pallisade formation

Table 1. Distribution of morbidity indicators of $S$. haematobium infection among subjects examined by age

\begin{tabular}{|c|c|c|c|c|}
\hline Age (years) & No. Examined & No. (\%) with infection & No. (\%) with proteinuria & No. (\%) with hematuria \\
\hline \multicolumn{5}{|l|}{ Children (y) } \\
\hline $4-10$ & 217 & $13(5.9)$ & $12(5.5)$ & $17(7.8)$ \\
\hline $11-17$ & 83 & $5(6.0)$ & $9(10.8)$ & $11(13.3)$ \\
\hline \multicolumn{5}{|l|}{ Adults (y) } \\
\hline $18-24$ & 6 & $0(0)$ & $0(0)$ & $2(33.3)$ \\
\hline $25-31$ & 8 & $0(0)$ & $0(0)$ & $0(0)$ \\
\hline $32-38$ & 17 & $0(0)$ & $0(0)$ & $0(0)$ \\
\hline $39-45$ & 11 & $0(0)$ & $0(0)$ & $0(0)$ \\
\hline $46-52$ & 4 & $0(0)$ & $0(0)$ & $0(0)$ \\
\hline $53-59$ & 4 & $0(0)$ & $0(0)$ & $0(0)$ \\
\hline Total & 350 & $18(5.1)$ & $21(6.0)^{*}$ & $30(8.5)^{\star \star}$ \\
\hline
\end{tabular}

${ }^{*} X^{2}=6.000, P=0.199 ;{ }^{* \star} X^{2}=6.000, P=0.199$ 


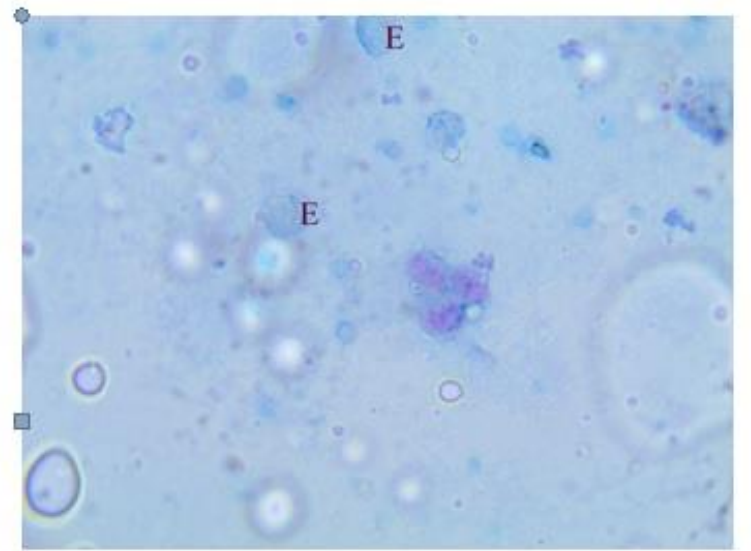

A: Hyaluronic acid-negative epithelial cell

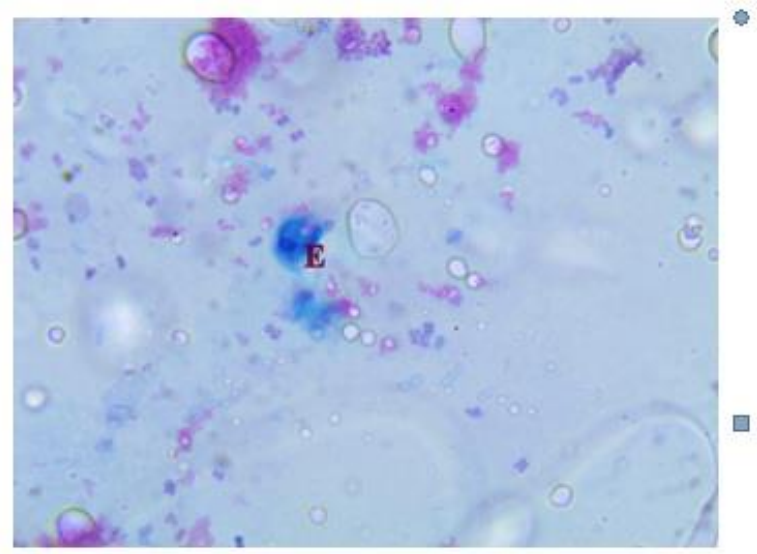

B: Hyaluronic acid-positive epithelial cell

Figure 1: Bladder epithelial cells negative and positive for hyaluronic acid. Plate A shows two palely-stained bladder epithelial cells $\mathrm{E}$ and Plate B shows a deep blue-stained bladder epithelial cell E positive for hyaluronic acid. Alcian blue 400x magnification.

Table 2. Distribution of morbidity indicators of $S$. haematobium infections according to gender of subjects examined

\begin{tabular}{lcccc}
\hline Gender & No. Examined & No. (\%) with infection & No. (\%) with proteinuria & No. (\%) with hematuria \\
\hline Children & 114 & $11(9.7)$ & $15(13.2)$ & $16(14.0)$ \\
Male & 186 & $7(3.8)^{*}$ & $6(3.2)$ & $12(6.5)$ \\
Female & & & & \\
Adults & 20 & 0 & $0(0)$ & $0(0)$ \\
Male & 30 & 0 & $0(0)$ & $2(6.6)$ \\
Female & 350 & $18(5.1)$ & $21(6.0)$ & $30(8.5)$ \\
Total & & & &
\end{tabular}

Table 3: Mean NMP of 22 of infected versus uninfected subjected by age.

\begin{tabular}{|c|c|c|c|c|c|c|c|}
\hline \multirow{2}{*}{$\begin{array}{l}\text { Patients } \\
\text { Age }\end{array}$} & \multirow[b]{2}{*}{$\mathbf{N}$} & \multicolumn{2}{|c|}{ Infected } & \multicolumn{4}{|c|}{ Uninfected } \\
\hline & & Mean NMP22 & SD & Age & $\mathbf{N}$ & Mean NMP22 & SD \\
\hline $4-10$ & 13 & 1611.97 & 613.145 & $4-10$ & 205 & 1217.6 & 478.5 \\
\hline $11-17$ & 5 & 1205.10 & 238.207 & $11-17$ & 77 & 1044.9 & 404.8 \\
\hline \multirow[t]{7}{*}{ Total } & 18 & 1498.95 & 560.259 & $18-24$ & 6 & 1265.0 & 339.6 \\
\hline & & & & $25-31$ & 8 & 1692.3 & 46.4 \\
\hline & & & & $32-38$ & 17 & 1343.4 & 319.4 \\
\hline & & & & $39-45$ & 11 & 727.0 & 260.7 \\
\hline & & & & $46-52$ & 4 & 1652.2 & 744.4 \\
\hline & & & & 53-59 & 4 & 1514.2 & 599.4 \\
\hline & & & & Total & 332 & 1188.8 & 468.6 \\
\hline
\end{tabular}

$\mathrm{F}=0.147, \mathrm{P}=0.864$ 


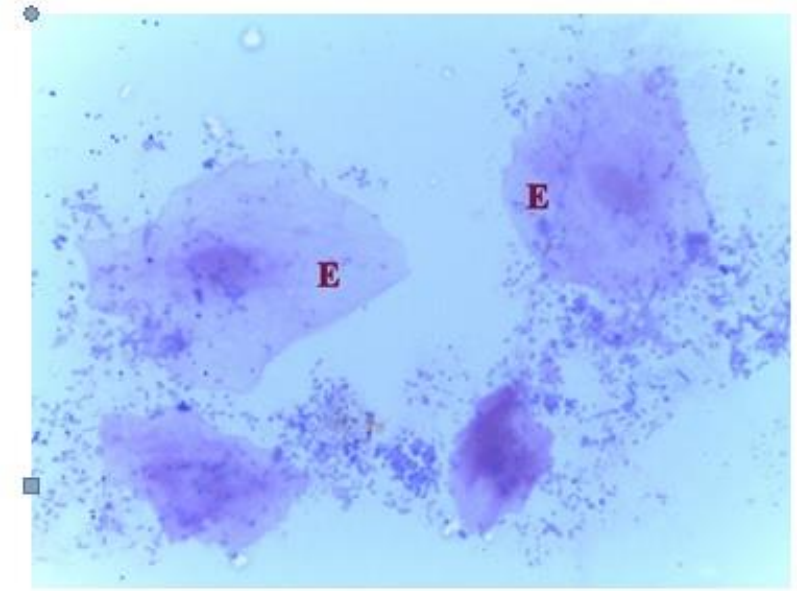

A: Normal epithelial cells

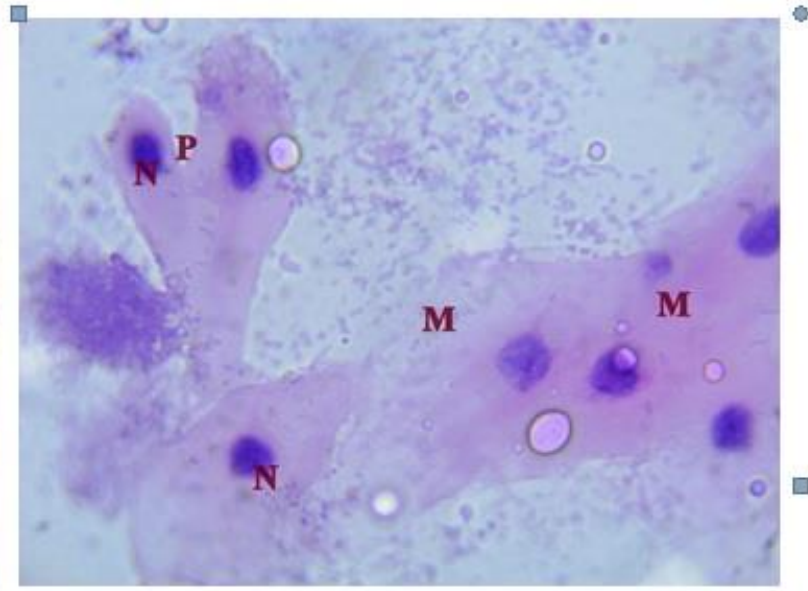

B: Metaplastic epithelial cells

Figure 2: Normal and metaplastic epithelial cells. Plate A shows normal epithelial cells $E$ with normochromic nuclei. Plate B shows metaplastic cells showing features of progression to cancer characterized by hyperchromatic nuclei $\mathrm{N}$, multinucleation with loss of cell membrane $\mathrm{M}$ and palisade formation P. Papanicolaou stain 1000X magnification.

Table 4. Mean NMP 22 of infected versus uninfected subjects by gender.

\begin{tabular}{lcccccc}
\hline Patients & & \multicolumn{3}{c}{ Infected } & \multicolumn{3}{c}{ Uninfected } \\
\cline { 3 - 7 } Gender & $\mathbf{N}$ & Mean NMP22 & SD & N & Mean NMP22 & SD \\
\hline Male & 7 & 1742.0 & 555.7 & 210 & 1184.4 & 462.5 \\
Female & 11 & 1344.3 & 529.8 & 122 & 1196.3 & 480.7 \\
Total & 18 & 1499.0 & 560.3 & 332 & 1188.8 & 468.6 \\
\hline
\end{tabular}

$\mathrm{F}=0.402, \mathrm{P}=0.676$

Table 5. Distribution of cytological findings of $S$. haaematobium among subjects examined by age.

\begin{tabular}{lcccc}
\hline $\begin{array}{l}\text { Age group } \\
\text { (years) }\end{array}$ & $\begin{array}{c}\text { No. } \\
\text { Examined }\end{array}$ & $\begin{array}{c}\text { No. (\%) with } \\
\text { infection }\end{array}$ & $\begin{array}{c}\text { No. (\%) with abnormal } \\
\text { epithelial cells }\end{array}$ & $\begin{array}{c}\text { No. (\%) positive for } \\
\text { hyaluronic acid }\end{array}$ \\
\hline $\begin{array}{c}\text { Children } \\
4-10\end{array}$ & 217 & $13(5.9)$ & $0(0)$ & $1(0.46)$ \\
$11-17$ & 83 & $5(6.0)$ & $0(0)$ & $0(0)$ \\
Adults & & & & $0(0)$ \\
$18-24$ & 6 & $0(0)$ & $0(0)$ & $0(0)$ \\
$25-31$ & 8 & $0(0)$ & $0(0)$ & $0(0)$ \\
$32-38$ & 17 & $0(0)$ & $0(0)$ & $0(0)$ \\
$39-45$ & 11 & $0(0)$ & $1(9.0)$ & $0(0)$ \\
$46-52$ & 4 & $0(0)$ & $0(0)$ & $0(0)$ \\
$53-59$ & 4 & $0(0)$ & $1(25)$ & $\mathbf{1}$ \\
Total & 350 & $\mathbf{1 8 ( 5 . 1 )}$ & $\mathbf{2 ( 0 . 5 7 )}$ & \\
\hline
\end{tabular}

Table 6. Distribution of cytological findings of $S$. haematobium according to gender of subjects. 


\begin{tabular}{ccccc}
\hline Gender & $\begin{array}{c}\text { No. } \\
\text { Examined }\end{array}$ & $\begin{array}{c}\text { No. (\%) with } \\
\text { infection }\end{array}$ & $\begin{array}{c}\text { No. (\%) with abnormal } \\
\text { epithelial cells }\end{array}$ & $\begin{array}{c}\text { No. (\%) positive for } \\
\text { hyaluronic acid }\end{array}$ \\
\hline $\begin{array}{l}\text { Children } \\
\text { Male }\end{array}$ & 114 & $11(9.7)$ & $0(0)$ & $0(0)$ \\
$\quad \begin{array}{l}\text { Female } \\
\text { Adults }\end{array}$ & 186 & $7(3.8)$ & $0(0)$ & $1(0.5)$ \\
Male & 20 & 0 & $0(0)$ & $0(0)$ \\
Female & 30 & 0 & $2(6.7)$ & $0(0)$ \\
Total & 350 & $18(5.1)$ & $2(0.6)$ & $1(0.29)$ \\
\hline
\end{tabular}

Fisher's exact $P=0.333$ Not significant

\section{DISCUSSION}

The endemicity of urinary schistosomiasis has been confirmed in Adim Community, Nigeira [5,7-10]. Several researchers in a way to control this infection in this community had administered different treatment regiments such as: praziquantel alone [14], artesunate alone [8], and praziquantel and artesunate [9] among others. However, with all these interventions, urinary schistosomiasis is still endemic in this community.

This work was carried out to screen both adult and children residents in this community to rule out the possibility of their being predispose to bladder cancer due to the endemicity of schistosomiasis.

The prevalence of $5.1 \%$ observed among children and adults in this study was far lower than that observed from previous studies in this area by Inyang-Etoh et al. [10] who observed a prevalence of $11.3 \%$ among adult only, InyangEtoh et al. [9] who observed $38.5 \%$ and Useh and Ejezie [7] who had $50.4 \%$ among children only. This prevalence rate was also lower than $38.5 \%$ obtained in Biase and Yakurr Local Government Areas by Adie et al. [11]. Perhaps the low prevalence rate observed in this study might be as a result of increased awareness and different researchers visiting the study area to administer treatment such as: praziquantel alone [14], artesunate alone [8], and praziquantel and artesunate [9]. Similar reduction from $38.5 \%$ to $0.17 \%$ was observed in Biase and Yakurr Local Government Areas after administration of praziquantel [11]. This prevalence of $5.1 \%$ can also be compared with other researches of $5.7 \%$ in Port-Harcourt by Arene et al. [15], 10\% in
Abriba, Abia state by Okolie [16], 18.7\% in Jos by Anyanwu and Okoro [17], and $21.9 \%$ and $91.4 \%$ in Ndokwa-East of Delta state by Nwabueze and Opara [18].

Children were the most affected in the study. This shows that children are more at risk of infection in the study area than adults because of their frequent engagement in water contact activities [10,19]. On the other hand, the absence of infection in adults may be attributed to several factors. They may have less exposure to water activities, or have undergone treatment of previous infections [8,9] or may have developed immunity to reinfection [19].

The age group 4-10 years and 11-17 years had the highest infection rate of $5.9 \%$ and $6.0 \%$ which still points to frequent water contact activities either for domestic or recreational purposes. Children of these age groups are more active in terms of recreation and domestic work than their parents. Similar observation was reported by Nwabueze and Opara [18].

Based on gender, males had more infection rates and most intense infections than females. This is similar to reports by Nwabueze and Opara [18] and Roberts and Janovy [19] who suggested that this is due to recreational or occupational exposure of the males. But, this is in contrast to previous study that had females as the most affected by Inyang-Etoh et al. [10].

In this study, the screening of NMP 22 among subjects in Adim Community was found to be negative for bladder cancer as the entire values recorded fell below $4000 \mathrm{pg} / \mathrm{ml}$. This shows that NMP 22 is useful for screening of bladder cancer as reported by Kumar et al. [20] and Barbieri et al. [21]. The mean NMP 22 values 
between the infected and uninfected subjects by age and gender were also not significant which shows that the schistosomiasis infection did not affect the NMP 22 values.

The cytological findings in the Papanicolaoustained smear showed that there was no abnormal epithelial cell found among the children aged 4-10 years and 11-17 years that were diagnosed with $S$. haematobium infection. This shows that $S$. haematobium-induced cellular abnormalities may take a long time to manifest in infected persons. This is because a long time will elapse before $S$. haematobium can cause mutations in DNA of the bladder epithelial cells as reported by Lokeshwar et al. [22]. The abnormal epithelial cells observed were found among female adults aged $39-45$ years $1(9.0 \%)$ and $53-59$ years $1(25 \%)$ but these subjects were not diagnosed with $S$. haematobium. It is believed that several factors may be attributed to this finding. First, these adults may be asymptomatic carriers of $S$. haematobium or have long-standing undetected chronic infections [19]. Its occurrence in females show that they may have had earlier exposure to $S$. haematobium at a younger age as observed by the work of Inyang-Etoh et al. [10] that more adult females are infected than males. Another reason may be that these adults are exposed to other risk factors of bladder cancer that cannot be easily established by this study. However, the detection of mild dysplasia and metaplasia as epithelial abnormalities reveal that these subjects are at risk of developing bladder cancer [23]. Dysplasia and metaplasia are epithelial changes that occur as a result of cellular injury. Infestation by $S$. haematobium cause mechanical erosion of the bladder epithelium and infiltration of chronic inflammatory cells which may produce free radicals. These free radicals can cause mutation of genes or activation of procarcinogens to form carcinogens, predisposing the epithelial cells to development of bladder cancer [23,24].

In the alcian blue-stained smears, hyaluronic acid-positive epithelial cells were found in $S$. haematobium infected children $4-10$ years 1 $(0.5 \%)$ although it was not statistically significant. This finding shows that hyaluronic acid can be useful in early detection of cellular changes in S. haematobium-infected persons. Hyaluronic acid is a glycosaminoglycan found in cells and helps maintain osmotic balanace as well as aid in tumour adhesion and angiogenesis [25]. Lokeshwar et al. [26] had stated that its staining in epithelial cells is associated with cancer. Thus, the presence of hyaluronic acid may be a predisposing factor to development of cancer in the affected persons.

It is obvious that urinary schistosomiasis is still endemic in Adim Community despite public awareness and treatments. This may be largely attributed to poor attitude of residents in embracing behavioral change towards the predisposing factors. However, this research has shown that there is reduction in prevalence rate and eradication can be possible if greater effort is intensified. It is worthy to note that residents who continue to harbor this parasite for a longer time may be predisposed to metaplasia, mild dysplasia and hyaluronic acid positive epithelial changes and subsequently to the development of bladder cancer.

There is need for integrated control measures which integrates treatment, better provision of pipe-borne water and continuous health education with greater emphasis on the pathology of the disease and risk of development of bladder cancer among infected persons. Behavioral change programs should be enshrined in schools and communities as a whole to improve compliance. Farmers should be educated on the need to use protected clothing while farming in the swarms.

\section{ACKNOWLEDGMENTS}

Declaration of Conflicting Interests: The authors declare that they have no conflict of interest.

Financial Disclosure: No financial support was received.

\section{REFERENCES}

1. World Health Organization. Schistosomiasis Number of People Treated Worldwide in 2013. Weekly Epidemiol Rec 2015; 5(90): 25-32. http://www.who.int/ schistosomiasis/en/

2. World Health Organization. Schistosomiasis Fact Sheet: 2014 No.115. (http://www.who.int/medicentre/factsheets/fs115/e $\mathrm{nl})$ 
3. Lokeshum VB, Habuchi T, Grossman HB. et al. Bladder tumor markers beyond Cytology: International Consensus Panel on Bladder Tumor Markers. Urology 2005; 66 (Supplement 6A): 3563.

4. Lokeshwar VB, Obek C, Soloway MS. Tumorassociated hyaluronic acid: A new sensitive and specific urine marker for bladder cancer. Cancer Res 1997; 57:773-777.

5. Ejezi, GC, Uko EK, Braide E. Schistosomiasis in Cross River State, Nigeria. Prevalence and Intensity of Infection on Admin Akamkpa Local Government Area. J Hyg Epidemiol Microbiol Immunol 1991; 35:141-147.

6. Useh MF, Ejezie GC. Prevalence of Morbidity of Schistosoma Haematobium Infection in Adim Community of Nigeria. J Med Lab Sc 1996; 5:1751.

7. Useh MF Ejezie GC. Modification on Behaviour and Attitude in the Control of Schistosomiasis. Observation in Water Contract Patterns and Perception of Infection. Annals Trop Med Hyg 1999; 93 (7): 711-720.

8. Inyang-Etoh PC, Ejezie GC, Useh MF, InyangEtoh EC. Efficacy of Artesunate in the Treatment of Urinary Schistosomiasis in an Endemic Community in Nigeria. Annals Trop Med Parasitol 2004; 98:491-499.

9. Inyang-Etoh PC, Ejezie GC, Useh MF and InyangEtoh EC. Efficacy of a combination of Praziquantel and Artesunate in the treatment of urinary Schistosomiasis in Nigeria. Transaction of the Roy Soc Trop Med \& Hyg 2009; 103: 38-44.

10. Inyang-Etoh PC, Anyanwu CJ, Udonkang MI, Equali VI. Cytological Findings in Urine of Adult Residents of Urinary Schistosomiasis Endemic Community in Cross River State, Nigeria. British $\mathrm{J}$ Med Med Res 2015; 8(11): 948-955.

11. Adie HA, Okon OE, Arong GA. Braide EI, Ekpo UF. Spatial Distribution of Urinary Schistosomiasis in Cross River State, Nigeria Using Geographical Information System and School Based Questionnaire. Pakistan J Biol Sc 2013; 16:1161172.

12. Chen MG, Mott KE. Progress in the assessment of morbidity due to Schistosoma haematobium infection. Trop Dis Bull 1989; 86: R1-R36.

13. Inyang-Etoh PC, Ejezie GC, Useh MF. Height as a surrogate for bodyweight for estimating the dosage of praziquantel and artesunate in the treatment of urinary schistosomiasis in school-age children. Mary Slessor J Med 2010; 10(1):29-37.

14. Ejezie GC, Udoh AE, Meremikwu MM, Odigwe $\mathrm{GO}$, Useh, MF. Some effects of annual treatment and re-treatment on morbidity indicators of urinary schistosomiasis. Mary Slessor J Med 1998; 1: 6772.
15. Arene FOI, Ukpeibo ET, Nwanze EA. Studies on schistosomiasis in the Nigeria Delta: Schistomiasis intercalatum in the urban city of Port Harcourt, Nigeria. Public Health 1989; 103: 295301.

16. Okolie NJC. Prevalence and intensity of urinary schistosomiasis among the Abriba people of Abia State, South Easthern Nigeria, J Internal Sci Res 2008; 1(2): 156-159.

17. Anyanwu Gl, Okoro KN. Observations on urinary schistosomiasis in school children in Jos, 27au State, Nigeria. International $J$ Eviron Health Human Dev 2002; 3(1): 31-34.

18. Nwabueze AA \& Opara OE. Outbreak of urinary schistosomiasis among school children in riverine communities of Delta state, Nigeria; impact of road and bridge construction. J Med Sc 2007; 7:572578.

19. Roberts LS \& Janovy JJ.Gerald D. Schmidt, Roberts L.S. Foundations of Parasitology. 8th ed. Boston: McGraw Hill Educational Foundation. 2009; 147-170.

20. Kumar A, Kumar R, Gupta NP. Comparison of NMP22 BladderChek Test and Urine Cytology for the Detection of Recurrent Bladder Cancer, Japan J Clinical Oncol 2006; 36(3): 172-175.

21. Barbieri CE, Cha EK, Chromecki TF, et al. Decision curve analysis assessing the clinical benefit of NMP22 in the detection of bladder cancer: Secondary analysis of a prospective trial. BJU Internal 2012; 109(5): 685-690.

22. Lokeshwar VB, Cerwinka WH, Lokeshwar BL. HYAL, Hyaluronidase: A Molecular Determinant of Bladder Tumour Growth and Invasion. Cancer Res 2005; 65:2243.

23. Botelho ME, Machado JC, Da Costa, JMC. Schistosoma haematobium and bladder cancer. Virulence 2009; 1(2):84-87.

24. Wu XR. Urothelial tumorigenesis: a tale of divergent pathways. Nat Rev Can 2005; 5: 713725.

25. Sullivan PS, Chan JB, Levin MR, Rao J. Amer J Trans Res 2010; 2(4): 412-440.

26. Lokeshwar VB, Robinwicz D, Schroeder, GL, et al. Stromal and epithelial expression of tumour markers hyaluronic acid and HYAL1 Hyaluronidase in prostate cancer. $\mathrm{J}$ Biol Chem 2001; 276(15):11922. 